\title{
Psychosocial Effect of Motivational Incentives on Senior Secondary Schools 'Teachers' Work Effectiveness in Adamawa State, Nigeria
}

\author{
Kwaji Tizhe Takwate \\ Department of Arts \& Social Sciences Education, Adamawa State University, Mubi \\ Email: taquate85@yahoo.com
}

\begin{abstract}
This study investigated the psychosocial effect of motivational incentives on Senior Secondary Schools teachers' work effectiveness in Adamawa State, Nigeria. The study adopted survey research design. The population of this study consisted of 162 school administrators and 74 teachers selected from 58 Government owned Senior Secondary Schools in Adamawa State, from a which a sample of 40 respondents were selected using purposive sampling technique. Motivational Incentives and Teachers' Effectiveness Questionnaire (MITEQ) was used for data collection. The findings of the study revealed that there is lack of service improvement, seminars, and inadequate provision of teaching and learning materials. Teachers are always internally motivated, inconsistent performance evaluation, promotions are not awarded as at when due, and issuance of query letters at slightest provocations by principals. The also revealed that, motivation is the backbone of effective service delivery. This study also revealed that motivational incentive has significant effect on teachers' work effectiveness and that there is no significant difference between male and female teachers' reaction and response to motivational incentives. No significant difference was found between different types of motivation incentives and their effect on senior secondary school teachers' work effectiveness in Adamawa State. The study recommended others that the government as a matter of urgency The study recommends the provision of regular performance enhancement seminars for teachers, adequate provision of teaching and learning materials, prompt payment of teachers' salary and other monetary incentives and teachers should be internally motivated on the job. For the incentive to have the intended impact on teachers the study recommend that it should be awarded only to those teachers who actually exhibit the intended behaviours and such incentives should be distributed based on collaborative performance rather than on individual performance.
\end{abstract}

Keywords: psychosocial-effect; motivation; incentives; work-effectiveness; fringe benefit; Job satisfaction

\section{Introduction}

The aim of teaching is to give students the necessary knowledge and skills to acquire and utilize resources during their lifetime. This aim can be achieved by carrying the real life with all its different aspects, tools and concerns into the learning and teaching environment by implementing different activities and approaches (Dermici, Kesler \& Kaya, 2010). Teachers vary how they use methods and teaching skills where they are properly motivated to carry out their task and responsibility while teaching.

Motivation are drives that initiate a person's behaviour to act in a certain way. For someone to act either positively or negatively depend on incentives that is available. Motivational incentives in the opinion of John and Manabete (2015) are the resources, perceptions, methods, activities used by management for the purpose of providing a climate 
that is conducive to the satisfaction of the varied needs of the employees so that they may become satisfied, dedicated and effective task performers. This entails that without motivational incentives there could be low productivity. In general, motivation of workers continues to remain a challenge to managers over the years, including the education sector. The Nigerian National Policy on Education implementation committee recognized teachers' plight when it recommended that teachers should be treated in such a way that they have job satisfaction (Ajayi, 2009). The relevance of job satisfaction and motivation also fall within the focus of school management and crucial to the growth of any educational system because professional knowledge, skills and competencies occur when one feels effective in one's behaviour (Oni, Nwajiubab \& Nwosuc, 2017).

The roles and contexts of motivational incentives as tools for teachers' effectiveness cannot be underemphasized because high motivation enhances productivity which is naturally in the interests of all educational systems (Ololube, 2005). However, issues of how to motivate teachers to give them more satisfaction with their jobs continued to engage the attention of governments, educational administrators and educational policy makers but without much success, because not much has been done to actually motivate the teachers and the resultant effects of this are its psychosocial effects that makes many people and even teachers to see the teaching profession as a gate-way or stepping-stone to better jobs. Many in the profession attempt to combine teaching with some other endeavours such as trading and thus distract their work performance (Meindinyo \& Ikurite, 2017).

Teachers' work effectiveness is a term used to refer to the degree to which teachers are able to translate educational objectives specified in the National Policy on Education into knowledge and skill and transfer them to students within the classroom. Any teacher that cannot do such cannot be termed as effective (Ukpong \& Uchendu, 2012). There are many factors that influence the lyceum teachers' job effectiveness such like aptitude, attitude, subject mastery, teaching methodology, personal characteristics, the classroom environment, general mental ability, personality, relations with students, preparation and planning, effectiveness in presenting subject matters, relations with other staff, self-improvement, relations with parents and community, poise, intellect, teaching techniques, interactions with students, motivational skills, fairness in grading and teachers' attitude toward the students among others (Nwosu, 2014). All these cannot materialise without an appropriate motivation package which serves as a boost for effectiveness.

Compared with other professions, teachers across Nigeria and Adamawa state in particular exhibit higher levels of emotional symptoms due to the fact that they are not provided with good quality training and development and to some they seem not to have the opportunities to further improve and thus, they remain demotivated when they see their learners perform poorly academically. Since then, series of accountability programs have been implemented that can mete out rewards or sanctions to teachers based on some function of school test scores, especially under the guise of the "No Child Left Behind Act". Teacher motivation plays an important role in the promotion of teaching and learning excellence because motivated teachers are more likely to motivate students to learn and ensure the implementation of educational reforms and feelings of satisfaction and fulfilment in the teaching profession. To redeem the present deplorable state of secondary education and teachers' productivity, teachers must be thoroughly furnished with the necessary tools and materials to teach. Thus, the crux of this study to assess the psychosocial effect of 
motivational incentives on Senior Secondary Schools teachers' effectiveness in Adamawa State, Nigeria.

\section{Statement of the Problem}

Since teachers' effectiveness is important, provision of adequate motivational incentives remain paramount by the school management. High productivity and good performance in schools cannot be realized without teachers support and contributions because teachers are expected to render a very high job performance and all the stakeholders are curious regarding the teachers' job performance, loyalty, patriotism, dedication, hard work and commitment. One may wonder if teachers, whose responsibility is to impart knowledge and inculcate discipline are really doing their work (Okon in Oni, Nwajiubab \& Nwosu, 2017).

Motivation gives teachers the incentive to work with ease considering the benefits attached. There have been deteriorating standards of professional conduct, including serious misbehaviour in and outside work, poor preparation of teaching material especially lesson notes, lack of continuous student assessment and general poor professional performance among teachers in Adamawa State which can be probably due to lack of enough motivational incentives prompt this research to determine the psychosocial effect of motivational incentives on Senior Secondary Schools teachers' work effectiveness in Adamawa State, Nigeria.

\section{Research Methods}

The scope of this study was limited to government owned senior secondary schools in Adamawa State, Nigeria. The study was delimited to determining the psychosocial effect of motivational incentives on teachers' work effectiveness. This study adopted survey research design. The population of the study consists of 162 school administrators and teachers of Government Senior Secondary Schools in Adamawa State, Nigeria. Simple random sampling was used to select 20 senior secondary schools from 58 senior secondary schools. Motivation Incentives and Teachers' Effectiveness Questionnaire (MITEQ) was used for data collection based on four-point Likert's scale. The instrument was pilot tested on all Government senior secondary schools within Numan education zone, Adamawa State which was not used in the final study. The internal consistency reliability coefficient of the instrument was 0.76 using Cronbach alpha statistic. Mean and standard deviation was used to answer the research questions and ANOVA and t-test was used to test all the null hypotheses. The decision to rate any item as agree/effective or disagree/ineffective was based on the midpoint of 2.50. Any item that yield a mean of $\geq 2.50$ was regarded as agree or effective and items which gave the mean $\leq 2.49$ was regarded as disagreed or ineffective. The decision to reject or accept any null hypothesis is, if $\mathrm{f}$-calculated or $\mathrm{t}$-calculated is higher than the f-critical or t-critical the null hypothesis is rejected, and the alternative accepted.

\subsection{Research Questions}

The following research questions guided the study:

1. What are the types of motivational incentives used to encourage Senior Secondary Schools teachers in Adamawa State, Nigeria?

2. What are the reactions of Senior Secondary Schools teachers to the motivational incentives provided in Adamawa State, Nigeria?

3. What is the level of Senior Secondary School teachers' motivation in Adamawa State, Nigeria?

4. To what extent does Senior Secondary School teacher's motivation translate to effective service delivery in Adamawa State, Nigeria? 
5. What is the level of Senior Secondary School teachers' work effectiveness in Adamawa State, Nigeria?

\subsection{Research Hypotheses}

The following null hypotheses were tested at a 0.05 level of significance.

HO1: Motivational incentives has no significant effect on teachers' work effectiveness in Adamawa State, Nigeria.

HO2: There is no significant difference between male and female teachers' reaction to motivational incentives in Adamawa State, Nigeria.

HO3: There is no significant difference between the effects of different types of motivation on senior secondary school teachers' work effectiveness in Adamawa State, Nigeria.

\section{Discussion}

\subsection{Results}

Research Question 1: What are the types of motivational incentives used to encourage Senior Secondary Schools teachers in Adamawa State, Nigeria? Result in Table 1:

Table 1. Mean and Standard Deviation of Motivation Incentives used to Encourage Senior Secondary School Teachers' in Adamawa State

\begin{tabular}{|c|c|c|c|c|c|}
\hline \multirow[t]{2}{*}{$\begin{array}{l}\mathrm{S} / \\
\mathrm{N}\end{array}$} & \multirow[t]{2}{*}{ Motivational Incentives } & \multicolumn{2}{|c|}{$\begin{array}{c}\text { School } \\
\text { Administrators }\end{array}$} & \multicolumn{2}{|c|}{ Teachers } \\
\hline & & $\bar{X}$ & SD & $\bar{X}$ & $\mathrm{SD}$ \\
\hline 1 & $\begin{array}{l}\text { Teachers are given regular on the job } \\
\text { training }\end{array}$ & 3.35 & 0.49 & 2.15 & 0.67 \\
\hline 2 & Regular performance enhancement seminars & 2.85 & 0.67 & 1.80 & 0.41 \\
\hline 3 & $\begin{array}{l}\text { Provision of adequate teaching and learning } \\
\text { materials }\end{array}$ & 2.20 & 0.62 & 2.35 & 1.42 \\
\hline 4 & $\begin{array}{l}\text { Teachers are always internally motivated for } \\
\text { the joy the find in teaching the subject }\end{array}$ & 3.80 & 0.41 & 2.85 & 0.37 \\
\hline 5 & Consistent performance evaluations & 2.15 & 0.37 & 3.00 & 0.79 \\
\hline 6 & Promotions as at when due & 2.20 & 1.20 & 2.00 & 0.00 \\
\hline 7 & $\begin{array}{l}\text { Issuance of query letters at slightest } \\
\text { provocations by principals }\end{array}$ & 2.30 & 0.47 & 2.95 & 0.76 \\
\hline & $\mathrm{G} \bar{X}$ & 2.69 & 0.60 & 2.44 & 0.63 \\
\hline
\end{tabular}

Results in Table 1 shows the grand mean 2.69 and 2.44 for school administrators and school teachers' responses on the various motivational incentives given to teachers in Adamawa state respectively. These indicate that school administrators have admitted that these incentives are used to encourage and motivate teachers to be effective which the teachers in their response negate to the contrary.

Research Question Two: What are the reactions of Senior Secondary Schools teachers to the motivational incentives provided in Adamawa State, Nigeria? Result in Table 2. 
Table 2. Mean Responses of Senior Secondary Schools Teachers' to Motivation Incentives

\begin{tabular}{|c|c|c|c|}
\hline $\begin{array}{l}\mathrm{S} / \\
\mathrm{N}\end{array}$ & Teachers' Reaction to Motivational Incentives & $\bar{X}$ & $\mathrm{SD}$ \\
\hline 8 & Teachers were always allowed to go for refreshal seminars & 2.40 & 0.82 \\
\hline 9 & Teachers were regularly given on-the-job training by the government & 2.80 & 0.41 \\
\hline 10 & $\begin{array}{l}\text { Teachers are allowed to initiate any teaching skill they deem fit for } \\
\text { their classroom }\end{array}$ & 2.90 & 1.02 \\
\hline 11 & $\begin{array}{l}\text { During the yearly performance evaluation teachers always resist } \\
\text { administration efforts for consistent } s\end{array}$ & 1.95 & 1.10 \\
\hline 12 & Teachers are promoted as at when due & 4.00 & 0.00 \\
\hline 13 & $\begin{array}{l}\text { Teachers discuss their problem(s) with the school administrator } \\
\text { democratically }\end{array}$ & 2.50 & 0.76 \\
\hline \multirow[t]{2}{*}{14} & $\begin{array}{l}\text { The school administrator delegate responsibility to teachers as the } \\
\text { need arise }\end{array}$ & 4.00 & 0.00 \\
\hline & $\mathbf{G} \overline{\boldsymbol{X}}$ & 2.94 & 0.59 \\
\hline
\end{tabular}

Table 2 shows a grand mean of 2.94 with a standard deviation of 0.59 , indicating that teachers' reactions to the available motivational incentives is positive. It signifies that teachers would be motivated to work at any slit provision of appropriate incentive.

Research Question Three: What is the level of Senior Secondary School teachers' motivation in Adamawa State, Nigeria? Result in Table 3.

Table 3. Perceived Level of Senior Secondary School Teachers' Motivation

\begin{tabular}{llcccc}
\hline & Items & \multicolumn{2}{c}{ School Administrators } & \multicolumn{2}{c}{ Teachers } \\
& & $\bar{X}$ & SD & $\bar{X}$ & SD \\
\hline 15 & daily motivation & 2.60 & 0.82 & 1.15 & 0.37 \\
16 & weekly motivation & 1.95 & 0.22 & 1.75 & 1.07 \\
17 & quarterly motivation & 2.25 & 0.44 & 1.15 & 0.37 \\
18 & yearly motivation & 1.00 & 0.00 & 2.40 & 0.68 \\
19 & overall motivation & 2.50 & 0.69 & 1.10 & 0.31 \\
& G $\bar{X}$ & 2.06 & 0.43 & 1.51 & 0.56 \\
\hline
\end{tabular}

Table 3 shows a grand mean of 2.06 and a standard deviation of 0.43 for schools' administrators and a grand mean of 1.51 and a standard deviation of 0.56 teachers indicating the overall perceived level of teachers' motivation in Adamawa State which low.

Research Question Four: To what extent does Senior Secondary School teacher's motivation translate to effective service delivery in Adamawa State, Nigeria? Result in Table 3.

Table 4. Extent to which Teacher's Motivation Translate to Effective Service Delivery in Adamawa State

S/ Items School Teachers




\begin{tabular}{llllll}
\hline $\mathrm{N}$ & \multicolumn{3}{c}{ Administrators } & & \\
& $\bar{X}$ & SD & $\bar{X}$ & SD \\
\hline 20 & $\begin{array}{l}\text { Motivated teachers do not deliver adequately in the } \\
\text { classroom }\end{array}$ & 1.00 & 0.00 & 1.55 & 0.51 \\
21 & $\begin{array}{l}\text { Motivation has nothing to do with effective service } \\
\text { delivery }\end{array}$ & 1.90 & 0.72 & 1.00 & 0.00 \\
22 & $\begin{array}{l}\text { Motivation is the backbone of effective service } \\
\text { delivery }\end{array}$ & 4.00 & 0.00 & 3.40 & 0.68 \\
$\mathrm{G} \bar{X}$ & 2.30 & 0.24 & 1.98 & 0.40 \\
\hline
\end{tabular}

As shown in Table 4 school administrators' mean perception of the extent to which teachers' motivation translate to effective service delivery is $2.30 \pm 0.24$ and $1.98 \pm 0.40$ for teachers. Both have agreed that the level of motivation given to teachers in the state do not translate to their effective service delivery.

Research Question Five: What is the level of Senior Secondary School teachers' work effectiveness in Adamawa State, Nigeria? Result in Table 5.

Table 5. Level of 'Teachers' Work Effectiveness in Adamawa State

\begin{tabular}{llllll}
\hline $\mathrm{S} /$ & Items & \multicolumn{3}{c}{$\begin{array}{c}\text { School } \\
\text { Administrators }\end{array}$} & \multicolumn{2}{l}{ Teachers } \\
$\mathrm{N}$ & & $\bar{X}$ & $\mathrm{SD}$ & $\bar{X}$ & $\mathrm{SD}$ \\
& & 2.40 & 0.75 & 3.00 & 0.00 \\
23 & teachers' effectiveness & 3.00 & 0.46 & 2.00 & 0.00 \\
24 & students passes external examinations & 2.05 & 0.83 & 3.00 & 0.00 \\
25 & teachers' classroom management techniques rating & 2.00 & 0.00 & 2.90 & 0.91 \\
26 & students passes in internal examinations & 2.06 & 0.43 & 1.51 & 0.56 \\
& G $\bar{X}$ & & & & \\
\hline
\end{tabular}

Table 5 shows mean perception of school administrators and teachers on the level of teachers' work effectiveness in Adamawa State to be $2.06 \pm 0.43$ and $1.51 \pm 0.56$ respectively, indicating the level of teachers' effectiveness in Adamawa State to below.

Hypothesis One: Motivational incentives has no significant effect on teachers' work effectiveness in Adamawa State, Nigeria. Result in Table 6.

Table 6. Effect of Motivational Incentives on teachers' effectiveness in Adamawa State

\begin{tabular}{|c|c|c|c|c|c|c|c|}
\hline Source of variable & $\mathrm{n}$ & $\begin{array}{l}\text { Sum of } \\
\text { squares }\end{array}$ & Df & $\begin{array}{l}\text { Mean } \\
\text { Square }\end{array}$ & F-cal & F-crit & Remark \\
\hline Between Groups & 4 & 8.10 & 3 & 2.70 & 9.92 & 2.86 & Significant \\
\hline Within Groups & 40 & 9.80 & 36 & 0.27 & & & \\
\hline
\end{tabular}

Table 6 indicate that motivation has no significant effect on teachers' effectiveness in Adamawa State since f-calculated 9.92 is higher than the f-critical (2.86). Therefore, the null hypothesis is rejected, and the alternative accepted. 
Hypothesis Two: There is no significant difference between male and female teachers' reaction to motivation incentives in Adamawa State, Nigeria. Result in Table 7.

Table 7. Summary of t-test on Teachers' Reaction to Motivation Incentives

\begin{tabular}{lccccccc}
\hline Variable & $\mathrm{n}$ & Mean & SD & Df & t-cal. & t-crit. & Remark \\
\hline Male & 8 & 2.13 & 1.25 & 7 & & & \\
& & & & & 1.36 & 4.44 & Not Significant \\
Female & 12 & 1.58 & 0.51 & 11 & & & \\
\hline
\end{tabular}

Table 7 shows that there is no significant difference between male and female teachers' response to motivational incentives in Adamawa state since t-calculated (1.36) is lower than the t-critical (4.44), therefore, the null hypothesis is accepted.

Hypothesis Three: There is no significant difference between the effects of different types of motivation on senior secondary school teachers' effectiveness in Adamawa State, Nigeria.

Table 8. Summary of t-test Statistic Effect of Types of Motivation on Teachers' Effectiveness

\begin{tabular}{lccccccl} 
Variable & $\mathrm{n}$ & Mean & $\mathrm{SD}$ & $\mathrm{df}$ & $\mathrm{t}$-cal. & $\mathrm{t}$-crit. & Remark \\
\hline Intrinsic motivation & 1 & 2.42 & 0.51 & 1 & & & \\
& & & & & 2.00 & 5.96 & Not Significant \\
Extrinsic motivation & 6 & 2.92 & 1.32 & 5 & & & \\
\hline
\end{tabular}

Table 8 shows a significant difference between different types of motivation and their effect on senior secondary school teachers' effectiveness in Adamawa state. At $\mathrm{P} \leq 0.05$ level of significance, the t-calculated (17.83) is higher than the t-critical (3.57), hence the null hypothesis was accepted.

\subsection{Discussion}

This study determined the psychosocial effect of motivational incentives on senior secondary school teachers' effectiveness in Adamawa State and revealed in Table 1 that regular job training, seminars, adequate instructional materials among others are given to teachers as perceived by school administrators which teachers' perception revealed that even if these incentives are provided it is minimal to encourage them to be effective in discharging their responsibilities. In support of the claims made by the teachers Avwerusuo (2017) study revealed that classroom teachers are not adequately motivated because the total motivational packages received by them do not commensurate with the present economy of the nation due to frequent inflation and high standard of living while Ondima et al (2014) supporting the views of the school administrators agreed that teachers benefited most from monetary motivators.

The finding in Table 2 found that teachers' motivation in relation to the incentives provided in Adamawa State is high due to the fact that they were sometimes allowed to attend 
seminars and they are promoted as at when due among others. This revelation is consistent with the finding of Tijana (2014) which agrees that teachers are likely to perceive some work related incentives to be motivational and such aid positive teachers' attitudes in relation to their teaching experience. Meindiyo and Ikurite (2017) also revealed that teachers respond positively to annual get-together parties, send-off parties, and less to constant supervision of work, attendance register and movement.

This study also revealed as shown in Table 3 that teachers' overall level of motivation is very low as perceived by the school administrators and teachers. This agreed with Kamoh, Ughili and Abada (2013) finding which revealed that teachers are consistently not motivated because of low income status, poor socio-economic status, lack of career advancement opportunities, high teacher-pupil ratio, poor work environment and inadequate fringe benefits when compared with other professions. These according to Nwakasi and Cummins (2018) determine how teachers effectively play their teaching roles though Orupabo and Nwankoala (2018) revealed that it all depend on how school administrators effectively use the intrinsic and extrinsic factors of motivation in an attempt to address teachers' problems.

The extent to which teachers' motivation translate to effective service delivery and the overall work effectiveness in Adamawa state was found to be low based on the perceptions of school administrators and teachers used for the study. John and Manabete (2015) agreed that lack of an effective motivation for teachers poses challenging consequences. Kongnuy (2015) in support of this revealed that boasting teachers' morale through promotions, good work environment and cordial interpersonal relationships positively influenced teachers' output. Amos and Loko (2015) findings also agree that self-respect, responsibility, and a sense of accomplishment as well as participatory school improvement, comprehensive staff development and supportive teacher evaluation hold great promise for improving teachers' professional motivation thereby making their effectiveness high.

The study (Table 6) revealed that motivation incentives have a significant effect on teachers' effectiveness in Adamawa State. In support of this, John and Manabete (2015) finding agree that teachers are ready to be committed to their work and perform optimally, if their motivation are given serious attention. Avwerosuo (2017) also agree that teacher's effectiveness is enhanced when they are adequately motivated. The study also revealed that there is no significant difference between male and female teachers' reaction to motivation incentives in the State. This according to Wanakacha, Aloka and Nyaswa (2018) exist because gender do not have effect on both intrinsic and extrinsic motivation of teachers to perform their core functions. The key factors that raised motivation of female teachers were the idea that they could be identified as having a job and that they were doing something while men are motivated when their job get them out of poverty.

The study (Table 8) revealed that there is no significant difference between the effects of different types of motivation on senior secondary school teachers' effectiveness in Adamawa state, Nigeria. This is in agreement with Meindiyo and Ikurite (2017) study which revealed that applying the right motivation factor such as annual get together parties, send-off parties for teachers on transfer, good working environment, constant supervision of teacher's work, provision of attendance register and provision of movement books have minimal influence on teachers' performance. 


\section{Conclusion}

The study recommends the provision of regular performance enhancement seminars for teachers, adequate provision of teaching and learning materials, prompt payment of teachers' salary and other monetary incentives and teachers should be internally motivated on the job. For the incentive to have the intended impact on teachers the study recommend that it should be awarded only to those teachers who actually exhibit the intended behaviours and such incentives should be distributed based on collaborative performance rather than on individual performance.

\section{References}

Ajayi, S. G. (2009). Statistical method for practice and research, Second Edition. Delhi: SAGE Amos, I. \& Loko, G. I. (2015). Assessment of teacher motivation approaches in the less developed countries. Journal of Education and Practice, 6(22): 10 - 17.

Avwerusuo, O. E. (2017). Motivation and teacher's effectiveness in the class work in Ughelli North Local Government Area of Delta State. Global Journal of Management and Business Research , 17(3): 9-18.

Dermici, A., Kesler, T. \& Kaya, H. (2010). Activity-based learning in secondary school geography lessons in turkey: A study from geography teachers' perspective. World Applied Sciences Journal, 11 (1): 53-63.

John, C. A \& Manabete, S. S. (2015). Teacher motivation and intervening influence of human factor on optimal productivity in secondary schools in Nigeria. Public Policy and Administration Research, 5 (12): 42 - 49.

Kamoh, N. M., Ughili, L. S., \& Abada, A. A. (2013). Enhancing the teacher profession: Key to revamping the education sector in Nigeria. Academic Research International: Social Sciences and Humanities, 4(1): 129 - 139.

Kongnuy, P. (2015). Motivation and changing fortunes in teachers' output: empirical evidence from selected secondary schools in North-West Region of Cameroon. Journal of Education and Practice, 6(5): 111 - 119.

Meindinyo R. O K \& Ikurite N (2017). Influence of motivation on teachers' performance in a local government area in Nigeria. IOSR Journal of Humanities and Social Science, 22 (5) Ver. 3 (May 2017): 22-28.

Nwakasi, C. C. \& Cummins, P. A. (2018). Teacher motivation and job satisfaction: A case study of North West Nigeria. Global Journal of Educational Research, 17(2018): 103112

Nwosu, J. C. (2014). Motivation and teachers' performance in selected public secondary schools in Ikenne Local Government Area of Ogun State. British Journal of Psychology

Research, 5(3): 40-50.

Nwoye, J. C. (2018). Influence of teachers' motivation on the academic performance of economic students in Dunukofia Local Government Area of Anambra State. Unpublished B. Sc. Department of Arts and Social Sciences Education, Godfrey Okoye University, Thinkers Corner, Emene, Enugu.

Okon, S. S. (2012). Effects of motivation on teachers' productivity in Delta State: Teachers' motivation and productivity. Canada: Lap Lambert Academic publishing. In O. A. Oni,

K. Nwajiubab. \& A. A. Nwosuc. Effects of teachers' effectiveness on students' academic performance in public secondary schools; Delta State - Nigeria. Journal of Educational and Social Research, 3(3): 105 - 111. 
Ololube, N. P. (2005). Benchmarking the motivational competencies of academically qualified teachers and professionally qualified teachers in Nigerian secondary schools. The African Symposium, 5(3): 17-37.

Ondima, C. et al. (2014). Effects of motivation on teacher's performance in kenyan schools: A survey of Nyamira District Secondary Schools in Nyamira County. Journal of Education and Practice, 5(30): $67-74$.

Oni, O. A., Nwajiubab, K. \& Nwosuc, A. A. (2017). Effects of teachers' effectiveness on students' academic performance in public secondary schools; Delta State - Nigeria. Journal of Educational and Social Research, 3(3): 105 - 111.

Orupabo, F. T. \& Nwankwoala, H. N. (2018). Teachers job motivation and quality education delivery in mission secondary schools. International Journal of Scientific Research in Education, 11(3B), 577-612.

Tijana, I. L. I. C. (2014). Geography teachers. attitudes toward self-evaluation: The case of Serbia. European Journal of Geography, 5(4): 78 - 86.

Upkong, N. N. \& Uchendu, C. C. (2012). Motivational strategies and possible influence on secondary school teachers' teaching performance. Global Journal of Educational Research, 11(2): 137-142.

Wanakacha, C. K., Aloka, P. J. O. \& Nyaswa, P. (2018) Gender differences in motivation and teacher performance in core functions in Kenyan secondary schools. Academic Journal of Interdisciplinary Studies, 7(1): 89 - 95. 